\title{
RTK signaling regulator SPRY2 associates with endocytic adaptor ITSN1 in vivo
}

\author{
O. V. Novokhatska, I. Ya. Skrypkina, M. V. Dergai, L. O. Tsyba, A. V. Rynditch
}

Institute of Molecular Biology and Genetics, NAS of Ukraine

150, Zabolotnoho Str., Kyiv, Ukraine, 03680

olga.novokhatska@gmail.com

\begin{abstract}
Aim. Mitogenic signaling from RTK (receptor tyrosine kinase) is tightly linked to endocytosis that regulates the fidelity of signal transduction. Intersectin 1 (ITSN1) is an evolutionarily conserved adaptor implicated in the earliest stages of clathrin-mediated endocytosis and involved in malignant transformation when overexpressed. The aim of this study was to find proteins that could connect ITSN1 to RTK signaling. Methods. In silico prediction of interaction motifs, expression of proteins in bacterial system and mammalian cell culture, immunoprecipitation, GST pull-down analysis, immunofluorescent studies. Results. Using «Scansite» service a binding of ITSN1 SH3A domain to signaling protein SPRY2 was predicted. For experimental verification of this interaction the GST fusion SH3 domains of ITSN1 were produced and purified from Escherichia coli. GST pull-down analysis showed that SH3A, N-SH3A (neuron-specific variant), SH3C and SH3E domains of ITSN1 were able to pull-down Flag$S P R Y 2$ from cell lysate. Immunofluorescent analysis together with coimmunoprecipitation indicated that OmniITSN1 and Flag-SPRY2 were partially colocalized and formed a complex in vivo. Conclusions. Our data showed that endocytic adaptor ITSN1 and signaling protein SPRY2 are associated in vivo presumably via PRD/SH3 interaction.
\end{abstract}

Keywords: intersectin 1, signaling, SPRY2, SH3 domain.

Introduction. Intersectin 1 (ITSN1) is conserved from nematodes to humans multidomain adaptor that is crucial for the initiation of clathrin-mediated endocytosis. Depletion of highly similar ITSN1 and ITSN2 scaffolding molecules together with Eps15 proteins abolishes clathrin-coated pits assembly [1]. Clathrin-mediated endocytosis is a common mechanism for internalization of activated receptor tyrosine kinases (RTKs) and regulation of mitogenic signaling.

Endocytic adaptor ITSN1 is involved in intracellular signal transduction through interaction with Ras activator SOS1, ubiquitin ligase $\mathrm{Cbl}$ and signaling protein CIN85 [2]. It was reported that overexpression of ITSN1 results in fibroblasts malignant transformation [3]. The aim of this study was to find other signaling molecules that could link ITSN1 to mitogenic signaling.

(C) Institute of Molecular Biology and Genetics, NAS of Ukraine, 2012
Materials and methods. Expression constructs and antibodies. The GST-SH3 domains of ITSN1 and Omni-ITSN1 were described previously [4]. The FlagSPRY2 was kindly provided by Dr. Susana de la Luna (Barcelona, Spain). Anti-Omni (D-8): sc-7270 antibody was purchased from «Santa Cruz Biotechnology» (USA). Anti-Flag antibody was purchased from «Sigma» (USA).

Binding assays and Western blot analysis. The GST fusion proteins were purified on glutathione-Sepharose 4B beads («GE Healthcare»). Lysates of HEK293 cells were prepared in extraction buffer that contained $20 \mathrm{mM}$ Tris-HCl, pH 7.4, $150 \mathrm{mM} \mathrm{NaCl,} 1 \%$ Triton X-100, $1 \mathrm{mM}$ PMSF. For pull-down assays, immobilized on beads GST-SH3 domains were incubated with cell lysates for $1 \mathrm{~h}$ at $4{ }^{\circ} \mathrm{C}$. For immunoprecipitation (IP), the cell lysate was incubated with antibodies and protein A/G Agarose beads («Santa Cruz Biotechnology») for $2 \mathrm{~h}$. Bound proteins were subjected to SDS-PAGE and immunoblotting. 
Cell culture and confocal microscopy. Adherent cell lines HEK293 and MCF-7 cells were maintained and transfected as described [5]. For immunofluorescent analysis fixed MCF-7 cells were incubated with the appropriate antibodies. Confocal images were taken using a Zeiss LSM510 microscope.

Results and discussion. Analysis of available data in the field of signaling from activated RTKs suggested SPRY2 (Sprouty 2) as a possible candidate for ITSN1 binding. This protein belongs to a family of SPRY proteins known to regulate signal transduction from flies to mammals [6]. SPRY2 possesses cysteine-rich domain common for all family members and contains at the Cterminus several proline residues (PRD) that could represent interaction motif for the SH3 domains. Using «Scansite» service (www.scansite.mit.edu) a binding of the SH3A domain to proline in position 307 of SPRY2 molecule was predicted. To test this possibility, the affinity purified GST-fused SH3 domains of ITSN1 were used to pull down Flag-SPRY2 from lysate of HEK293 cells expressing this protein. Obtained results showed that the $\mathrm{SH} 3 \mathrm{~A}$, as well as its neuron-specific variant $(\mathrm{N}$ SH3A), SH3C and SH3E domains interacted with Flagtagged SPRY2 in vitro (Fig. 1, A). To study this interaction in vivo HEK293 cells were cotransfected with constructs encoding Omni-ITSN1 and Flag-SPRY2. Using antibodies against Omni-tag SPRY2 was precipitated from cell lysate together with ITSN1 (Fig. 1, B).

Immunofluorescent studies were used to investigate the intracellular distribution of ITSN1/SPRY2 protein complexes. In quiescent cells SPRY2 is associated with microtubules and translocates to the membrane ruffles upon EGF-stimulation [7]. In serum-starved cells coexpressing Omni-ITSN1 and Flag-SPRY2 these proteins were spatially separated (Fig. 2, A) but displayed partial colocalization when supplemented with FBS (Fig. $2, B)$.

Accumulated data indicate that SPRY proteins are sensors and integrators of signaling [6]. In this study we demonstrated an in vivo complex formation between SPRY2 and endocytic adaptor ITSN1. A direct interaction between these molecules was mediated by binding of proline-rich motif of SPRY2 to the SH3 domains of ITSN1. Regarding that several SH3 domains were able to pull down signaling protein, a role of ITSN1 in clustering a few SPRY2 molecules could be suggested. Ano-
A

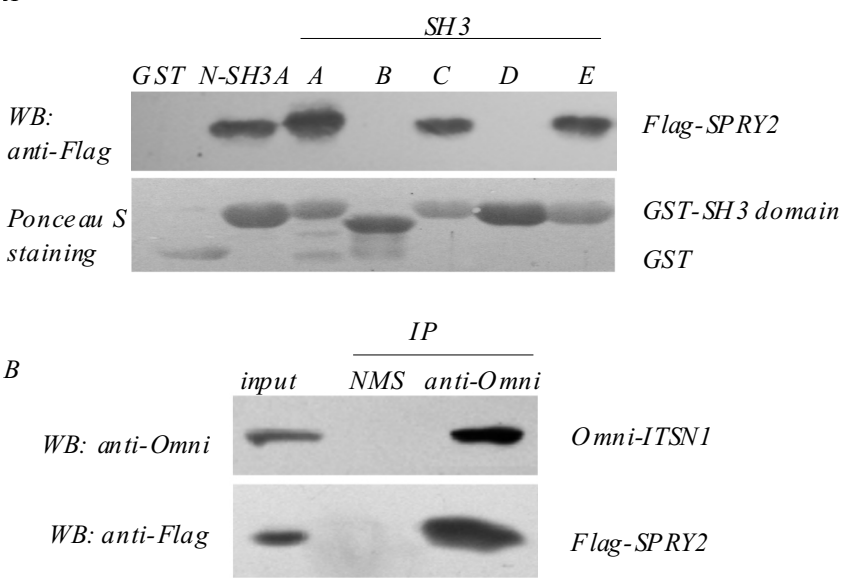

Fig. 1. ITSN1 interacts with SPRY2 in vitro and in vivo: $A$ - GST-fused SH3 domains of ITSN1 were incubated with extracts of HEK293 cells expressing Flag-SPRY2 (GST-fused proteins were visualized with Ponceau S staining, Flag-SPRY2 was detected using antibodies against tag); $B$ - HEK293T cells were cotransfected with Omni-ITSN1 and Flag-SPRY2 (cell extracts were subjected to immunoprecipitation with anti-Omni antibodies; protein complexes were analyzed by Western blotting using anti-Omni and anti-Flag antibodies); NMS - normal mouse serum

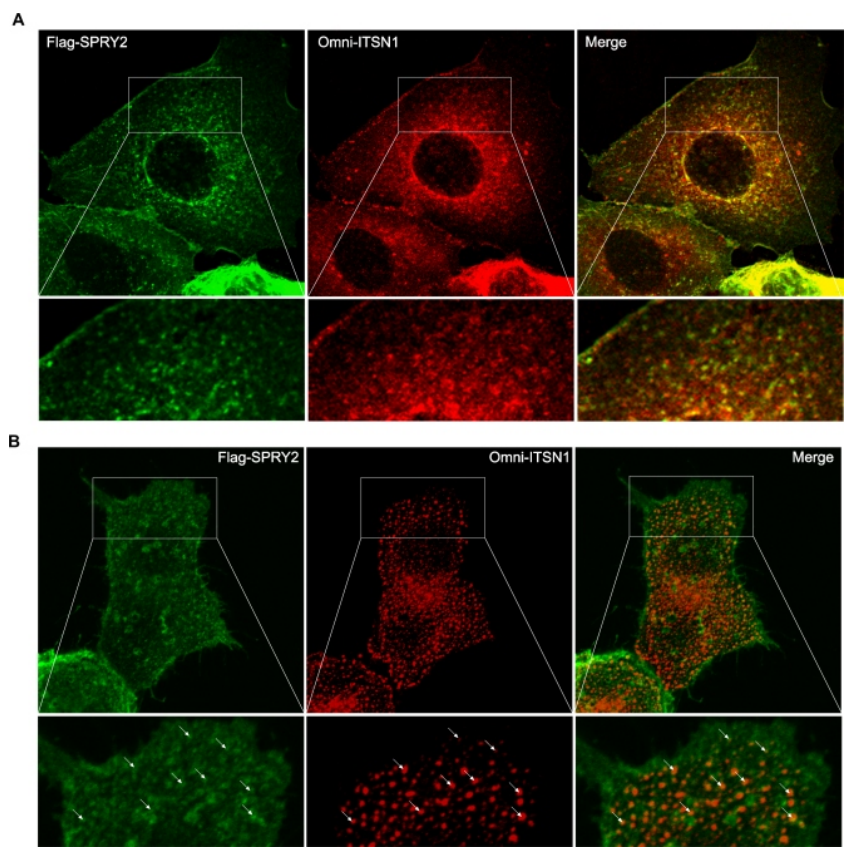

Fig. 2. Adaptor protein ITSN1 and signaling protein SPRY2 partially overlap in MCF-7 cells. Cells were cotransfected with Omni-ITSN1 and Flag-SPRY2 and starved for $24 \mathrm{~h}(A)$ or supplemented with FBS $(B)$. Proteins were stained with primary antibodies against tags and visualized with secondary antibodies conjugated to Texas Red or Alexa488 
ther possibility is bringing together signaling regulators SPRY2 and Cbl that are functionally linked and both interact with the SH3 domains of ITSN1. Our previous results showed that ITSN1 and Cbl form a complex in vivo independently of growth factor stimulation [5]. Contrary to this ITSN1 and SPRY2 displayed distinct localization in quiescent cells but partially overlapped when supplemented with FBS. Obtained data could suggest recruitment of SPRY2 to preexisting ITSN1/Cbl complex after growth factor stimulation. This question remains a challenge for future investigations.

\section{О. В. Новохацька, І. Я. Скрипкіна, М. В. Дергай, Л. О. Циба, A. В. Риндич}

Регулятор передачі мітогенного сигналу SPRY2 формує комплекс з адапторним білком ITSN1 in vivo

Резюме

Передача мітогенного сигналу від рецепторних тирозинкіназ (RTK) у клітині тісно пов 'язана з ендочитозом, який регулює точність такої передачі. Інтерсектин 1 (ITSN1) - ие еволюиійно консервативний адапторний білок, щчо бере участь у найбільш ранніх етапах клатрин-опосередкованого ендочитозу та залучений до проиесу злоякісної трансформації за умов надекспресії. Мета. Пошук білків, які можуть забезпечити зв 'язок ITSN1 із процесом передачі сигналу від RTK. Методи. Передбачення мотивів взаємодіï in silico, експресія білків у бактерійній системі та культурі клітин ссавиів, імунопреципітація, преципітація білків, злитих з GST, імунофлуоресцентні дослідження. Результати. За допомогою сервicy «Scansite» передбачено зв'язування домену SH3A ITSN1 із SPRY2. Для експериментального підтвердження иієє̈ взаємодї злиті з GST SH3-домени ITSN1 отримано і очищено з бактерій Escherichia coli. Використовуючи преципітацію білків, злитих з GST, встановлено, щзо домени $S H 3 A, N$-SH3A (нейрон-специфічний варіант), SH3C і SH3E ITSN1 здатні прециипітувати Flag-SPRY2 з лізату клітин. Дані імунофлуоресиентного аналізу та коімунопреиипітації свідчать про часткову колокалізачію білків Oтпі-ITSN1 $i$ Flag-SPRY2 та формування ними комплексу in vivo. Висновки. Отримані дані підтверджують асоціацію ендоцитозного адапторного білка ITSN1 із сигнальним білком SPRY2 in vivo.

Ключові слова: інтерсектин 1, передача мітогенного сигналу, SPRY2, домен SH3.

О. В. Новохачкая, И. Я. Скрипкина, Н. В. Дергай, Л. А. Цыьба, А. В. Рындич

Регулятор передачи митогенного сигнала SPRY2 ассоциирован с адапторным белком ITSN1 in vivo

Резюме

Передача митогенного сигнала от RTK (рецепторных тирозиновых киназ) тесно связана с эндоцитозом, регулирующим ее точ- ность. Интерсектин 1 (ITSN1) - эволюциионно-консервативный адапторный белок, вовлеченный в самые ранние стадии клатринопосредованного эндоцитоза, а также в злокачественную трансформацию в случае его сверхэкспрессии. Цель. Поиск белков, способных обеспечивать связь ITSN1 с прочессом передачи сигнала от RTK. Методы. Экспрессия белков в бактериальной системе и в культуре клеток млекопитающих, иммунопреиипитация, прещипитация белков, слитых с GST, иммунофлуоресцентный анализ. Peзультаты. С применением сервиса «Scansite» предсказано связывание домена SH3A ITSN1 с SPRY2. Для экспериментального подтверждения этого взаимодействия GST-слитые домены ITSN1 получены и очищены из клеток Escherichia coli. Используя преципитаичю белков, слитых с GST, установлено, что домены SH3A, N-SH3A (нейрон-специфический вариант), SH3C и SH3E способны преципитировать SPRY2-Flag из лизата клеток. Данные иммунофлуоресцентного анализа и коиммунопреципитации свидетельствуют о частичной колокализации белков Omni-ITSN1 и Flag-SPRY2 и формирование ими комплекса in vivo . Bыводы. Полученные данные подтверждают ассочиацию эндоцитозного адапторного белка ITSN1 с сигнальным белком SPRY2 in vivo.

Ключевые слова: интерсектин 1, передача митогенного сигнала, SPRY2, домен SH3.

\section{REFERENCES}

1. Henne W. M., Boucrot E., Meinecke M., Evergren E., Vallis Y., Mittal R., McMahon H. T. FCHo proteins are nucleators of clathrin-mediated endocytosis // Science.-2010.-328, N 59833.P. 1281-1284.

2. Tsyba L., Nikolaienko O., Dergai O., Dergai M., Novokhatska O., Skrypkina I., Rynditch A. Intersectin multidomain adaptor proteins: regulation of functional diversity // Gene.-2011.-473, N 2.P. 67-75.

3. Adams A., Thorn J. M., Yamabhai M., Kay B. K., O'Bryan J. P. Intersectin, an adaptor protein Involved in clathrin-mediated endocytosis, activates mitogenic signaling pathways // J. Biol. Chem.-2000-275, N 35.-P. 27414-27420.

4. Dergai O., Novokhatska O., Dergai M., Skrypkina I., Tsyba L., Moreau J., Rynditch A. Intersectin 1 forms complexes with SGIP1 and Reps1 in clathrin-coated pits // Biochem. Biophys. Res. Commun. -2010.-402, N 2.-P. 408-413.

5. Dergai M., Skrypkina I., Dergai O., Tsyba L., Novokhatska O., Filonenko V., Drobot L., Rynditch A. Identification and characterization of a novel mammalian isoform of the endocytic adaptor ITSN1 // Gene.-2011.-485, N 2 P. 120-129.

6. Guy G. R., Jackson R. A., Yusoff P., Chow S. Y. Sprouty proteins: modified modulators, matchmakers or missing links? // J. Endocrinol.-2009.-203, N 2.-P. 191-202.

7. Lim J., Wong E. S., Ong S. H., Yusoff P., Low B. C., Guy G. R. Sprouty proteins are targeted to membrane ruffles upon growth factor receptor tyrosine kinase activation. Identification of a novel translocation domain // J. Biol. Chem.-2000.-275, N 42.P. 32837-32845. 